\title{
Left ventricular systolic dysfunction in chronic kidney disease: from asymptomatic changes in geometry and function to overt heart failure
}

\section{Disfunzione sistolica del ventricolo sinistro nella malattia renale cronica: dalle alterazioni asintomatiche della geometria e della funzione, allo scompenso cardiaco conclamato}

\author{
Giovanni Cioffi1, Luigi Tarantini2, Pompilio Faggiano3, \\ Giovanni Pulignano4, Giulia Russo5, Andrea Di Lenarda5
}

\begin{abstract}
Left ventricular systolic dysfunction in chronic kidney disease: from asymptomatic changes in geometry and function to overt heart failure. G. Cioffi, L. Tarantini, P. Faggiano, G. Pulignano, G. Russo, A. Di Lenarda.

A bidirectional relationship between kidney and heart function is present in all stages of cardiac and renal disease, from the asymptomatic phase of left ventricular systolic dysfunction to overt heart failure, as well as from the initial reduction of glomerular filtration rate to end-stage kidney dis-
\end{abstract}

ease, respectively. The simultaneous presence of both diseases has a significant impact on prognosis and requires specific therapeutic strategies. The early recognition of abnormalities of renal and myocardial function may have a relevant influence on management of combination of these conditions.

Keywords: heart failure, end-stage kidney disease, glomerular filtration rate, left ventricular dysfunction.

Monaldi Arch Chest Dis 2014; 82: 10-15.

\footnotetext{
I Echocardiography Laboratory, Villa Bianca Hospital, Trento, Italy.

2 Department of Cardiology, Ospedale S. Martino, Belluno, Italy.

3 Cardiology Unit, Spedali Civili Brescia, Italy.

${ }^{4}$ Heart Failure Clinic. Division of Cardiology/C.C.U. San Camillo Hospital, Rome, Italy.

5 Cardiovascular Center, Health Authority $n^{\circ} 1$ and University of Trieste, Italy.
}

Corresponding author: Giovanni Cioffi, MD; Department of Cardiology; Villa Bianca Hospital; Via Piave 78, I-38100 Trento; Tel:39-0461-916000; Fax:39-0461-916874; E-mail address: gcioffi@villabiancatrento.it

\section{Introduction}

Left ventricular (LV) systolic dysfunction (LVSD) and chronic renal disease (CKD) repeatedly co-exist due to the increasing age of the general population, the reduction of renal perfusion due to the impairment of systolic cardiac performance and the tailored treatment of both states [1]. These two conditions have common predisposing causes such as hypertension, type 2 diabetes mellitus (T2DM), obesity and atherosclerosis, so that they share the same pathophysiological mechanisms. People with CKD have high rates of cardiovascular events, particularly when proteinuria is present $[2,3]$, and this condition should be regarded as a coronary heart disease risk equivalent [4]. Furthermore, the negative impact of CKD on clinical outcomes in patients with acute or chronic heart failure (HF) has been clearly identified [5-7], and in those patients in whom CKD coexists with T2DM, the mortality rate is particularly high, above all the cardiovascular one [8].

In this review, we tried to describe the natural history of LV geometry and systolic function of a heart beating in a patient with CKD, starting from the early changes during the asymptomatic phase of cardiac disease to the culmination of overt HF.
Asymptomatic changes in LV geometry and systolic function in CKD

In patients with CKD, LV mass typically increases in a concentric fashion, paralleling the progression of renal dysfunction [9, 10]. Several investigations analyzed LV structure and geometry in these subjects, focusing on the prevalence of traditional hypertrophy (established near to $40 \%$, approximating $75 \%$ at the time of dialysis initiation) and on the description of different LV geometric patterns [9-13]. The hemodynamic alterations induced by CKD (increased preload and afterload) certainly play an important role in changing LV geometry, but in point of fact, they explain only in part the development of concentric remodeling/hypertrophy in these patients [14]. Some investigations conducted in patients with CKD, indeed, documented the lack of correlation between echocardiographic findings and blood pressure levels $[14,15]$ suggesting that additional causes other than hemodynamic abnormalities (including neuro-hormonal stressors and factors inducing myocardial fibrosis and apoptosis) might produce an excess of LV mass $[15,16]$. Such behavior, consisting in a myocardial tissue growth 
exceeding the hemodynamic needs has been reported by several studies [17-22] and has been called "inappropriate LV mass" (iLVM), assessed as the ratio between observed and predicted LV mass (calculated from stroke work, gender and body size) [23].

iLVM has been found in a significant proportion of patients with arterial hypertension or aortic stenosis and has been associated with unfavorable cardiovascular profile and adverse prognosis [1722]. Recently, in a specific study aimed to assess the prevalence of iLVM in patients with CKD [24], we investigated 340 subjects without overt cardiac disease (mean age $68 \pm 13$ years, 37\% women), prevalently hypertensives (94\%) and one quarter with T2DM, who had a mean estimated glomerular filtration rate (eGFR) of $67 \pm 19$ $\mathrm{ml} / \mathrm{min} / 1.73 \mathrm{~m}^{2}$. iLVM was found in 146 of these patients $(43 \%)$ and in 7 healthy controls $(10 \%$; $p<$ 0.001). Prevalence of iLVM, as well as LV traditional hypertrophy, paralleled the severity of renal dysfunction ranging from $10 \%$ and $43 \%$ in stage 1 CKD patients to $100 \%$ and $100 \%$ in stage 5 CKD patients, respectively. eGFR was $23 \%$ lower $(57 \pm 19$ vs $74 \pm 16, p<0.01)$ in patients with iLVM than in those with appropriate LV mass. Our results were faultlessly in line with those reported by Nardi et al. [25] who found in a large group of patient with hypertension a prevalence of iLVM of $53 \%$ which was increasingly higher (38 up to $80 \%$ ) from stage 2 to 5 CKD. In our study [24], beyond lower eGFR, iLVM was closely and positively associated with higher LV relative wall thickness, LV mass index and, in particular, with lower LV midwall shortening. This was not a surprising finding. It is well-known, indeed, that changes in LV geometry towards a concentric fashion are closely related to impairment of LV midwall mechanics which may be lessened even though conventional echocardiographic indexes of chamber function, such as LV ejection fraction (LVEF), remain normal [26, 27]. This condition can be valuably revealed by the assessment of midwall shortening, which identifies early systolic impairment of circumferential LV myocardial fibers (the myocardial compartment mainly deputed to the pump function) [27]. The impairment of midwall shortening is an early and reliable indicator of the transition phase between normal cardiac function and clinically manifest HF [28] as well as a potent predictor of adverse cardiovascular outcomes in patients with hypertension [29], T2DM [30] and in the subsection of patients with chronic HF in whom LVEF is preserved [31]. In our experience [24], prevalence of impairment of midwall shortening was progressively higher ( $25 \%$ up to $42 \%, 64 \%, 89 \%$ and $100 \%$ ) from stage 1 to 5 CKD, clearly indicating a extensive presence of subclinical LVSD, beside changes in LV geometry, in most of people with moderate to severe CKD without clinical signs or symptoms of cardiac disease. All these findings provide reasonable enlightenments on the high cardiovascular morbidity and mortality of patients with CKD and, in particular, explain why they are so susceptible to develop HF.

\section{CKD and symptomatic LV systolic dysfunction}

The patho-physiological disadvantages of the excessive LV mass growth were well described many years ago in some pioneering experiences conducted on uremic rats $[32,33]$. Since that time, it was clear that CKD was a "metabolic" condition inducing LV hypertrophy by a number of hemodynamic and non-hemodynamic mechanisms. Among the latter, those activated by growth factors, protooncogenes, plasma noradrenalin, cytokines and angiotensin II play a central role in activating the intracellular processes that accelerate myocardial fibrosis and apoptosis [34], and alterated protein synthesis leading to the building of anomalous sarcomeres, as shown by the re-emergence of fetal muscle-specific gene products in deteriorating hearts put through chronic LV overload [35]. What we are describing is just the molecular biology of LVSD, which inexorably leads to a failing heart and to the HF syndrome after an asymptomatic phase lasting a variable time depending on the compensatory capacities of the individual cardiovascular system.

\section{Acute HF and CKD}

Some lines of evidences demonstrate the development of acute HF in patients with concomitant CKD is increasing [36, 37] suggesting the existence of several contributory factors beside the patho-physiological mechanisms consequential to CKD mentioned below. Once HF develops, renal hypo-perfusion occurs in a straight line by the reduction of cardiac output, but also indirectly through the activation of several neuro-hormonal mechanisms [38-40]. In this clinical state, the management of pharmacological and non-pharmacological therapy represents a difficult task [40, 41] since the treatment of congestion may aggravate renal function, a complication particularly frequent (ranging from 20 to $29 \%$ of patients in various experiences) in acute-stage HF [42-46]. Such a situation is associated with prolonged clinical destabilization and hospital stay, and is a powerful prognosticator of adverse clinical outcome [36, 37, 4247]. Due to all these reasons, the attention of researchers has been progressively increased in the last years and a lot of experiences have been published on this issue. However, no clinical investigation has been specifically dedicated to the patients with acute $\mathrm{HF}$ and concomitant severe CKD in the past. Furthermore, the systematic exclusion of these subjects from the most of the largest therapy-intervention and device trials impacts the results of the meta-analyses (which prevalently have considered middle-aged male patients with many other characteristics far from those of HF patients of the real word), so that few clinical and prognostic information on these patients are available [48]. As a result, we recently defined clinical features and prognostic markers for short and midterm mortality in patients with severe CKD hospitalized for an episode of acute HF [49] and recruited in the Italian registry "IN-HF Outcome" [50]. In this study [49], we selected the 455 pa- 
tients belonging to the lowest quartile of eGFR (mean value $28 \pm 9 \mathrm{ml} / \mathrm{min} / 1.73 \mathrm{~m} 2$ ). The study demonstrated that: 1) the in-hospital and 1-year mortality rates of these patients were dramatically high (13.6\% and $43.5 \%$, respectively), resulting more than two-fold higher than the total population of patients admitted to hospital for an episode of acute HF; 2) cardiovascular etiology of in-hospital and 1-year death was largely prevalent in comparison with other possible causes which were limited to a minority of cases; 3 ) predictors of in-hospital mortality were an abnormal status of consciousness, older age, hypo-natriemia, lower systolic blood pressure and eGFR. These results are in line with those found in patients enrolled in the ADHERE registry [51] and in the OPTIMIZE-HF registry $[52,53]$, in which in-hospital mortality was $8 \%$ and $4 \%$, respectively, and show that the negative impact of CKD on in-hospital outcome is proportional to the degree of CKD. Indeed, although our HF people were selected for having very low eGFR, eGFR itself was one of the strongest independent predictors of in-hospital death, suggesting that no inferior limit exists of renal function for which the prognostic value of eGFR vanished.

A final consideration regards the pharmacological therapy, analyzed in depth by Tarantini et al. [54] in the setting of acute HF patients enrolled in the Italian registry "IN-HF Outcome". At hospital admission, patients with moderate-severe CKD were receiving more frequently diuretics, angiotensin converting enzyme-inhibitor (ACEi) or angiotensin receptor blockers (ARBs) than those with normal or mildly impaired renal function. During hospitalization, diuretics are given at higher dose and for a longer time during the hospital stay while beta-blockers, digoxin, anti-aldosterone agents, ACEi and ARBs are given less frequently in the former than in the latter. These behaviors will have relevant impact on prognosis during the chronic phase of disease.

\section{Chronic HF and CKD}

Renal impairment in patients with chronic HF is recognized as an independent risk factor for morbidity and mortality [5, 6, 36, 37, 55, 56]. Data from the SOLVD trial quantified specific clinical predictors of reduction in renal function in patients with chronic HF who were prescribed ACEi therapy [57]. Enalapril use caused a 33\% increase in the risk of decreased renal function in these patients. Diuretic use and advanced age significantly increased this risk. Diabetes was associated with an increased risk of renal impairment in all patients with chronic $\mathrm{HF}$, but this risk was reduced in the enalapril group compared with the placebo group. Interestingly, beta-blocker therapy and higher LV ejection fraction were renoprotective in all patients regardless of therapy (enalapril or placebo). Ahmed et al. [58] recently demonstrated that discharge prescription of ACEi/ARB was associated with a modest but significant reduction in all-cause mortality in older patients with systolic $\mathrm{HF}$ with $\mathrm{CKD}$, including those with more advanced renal impairment, confirming that the well-known decrease in renal function produced by ACEi administration, when limited to $20-30 \%$ of the eGFR value at baseline, has not detrimental effects on the long-term prognosis also in patients with CKD.

Despite the greater risk of mortality in patients with chronic HF and CKD, evidence has suggested that guideline-recommended therapies for $\mathrm{HF}$ are less likely to be provided to patients with comorbid chronic HF and CKD [57, 59-61]. In our experience cited above [49], we observed that patients who died were taking during follow-up less frequently diuretics and beta-blockers than those who survived, indicating possible history of intolerance, specific contraindications or evidence of side effects. Furthermore, we also documented that, among patients treated with beta-blockers during the period of observation, those who died were receiving a significantly lower dose of carvedilol than patients who survived. Several data consistently indicated the lack of treatment with beta-blockers or of reaching their target doses as a clinical marker of severity of cardiac disease related to poorer clinical outcomes in patients with chronic HF [62-66]. Even ACEi/ARB were less frequently given to our patients who died during 1year follow up, mirroring a common practice attributable to lack of evidence of benefit and concern for potential harmful effects [67-69]. However, this medical behavior did not influence the outcome of our patients when adjusted for the other predictors. This result is reasonable in light of the results of several studies indicating the existence of a link between the worse clinical conditions at the time of hospitalization associated with older age $[52,53,70]$ and the adverse outcome in our patients with severe CKD and acute HF. In this situation, the protective renal and cardiac effect of ACEi/ARB might play a less important role on outcome than that documented in patients with stable chronic HF without severe CKD [71], so that a reduction of the dose of ACEi may be take into account, considering the results of Pita-Fernández et al. [72] who showed in elderly HF patients with CKD an improvement in anaemia and kidney function, and an increased survival rate.

\section{Conclusions}

Most patients with CKD have LVSD. This mirrors the influence of parenchymal CKD, renal artery disease, renal congestion and hypo-perfusion, neuroendocrine stimulation and the effects of pharmacological treatments. CKD negatively influences clinical outcomes both in primary and secondary prevention, in particular when HF syndrome develops. In the setting of asymptomatic patients with LVSD, the most important objective should be fight LV concentric remodeling/hypertrophy using ACEi/ARB, calcium antagonists and anti-aldosterone agents, the three classes of drugs with proved effects on the LV mass growth. Once the cardiac disease progresses towards HF, preventing CKD, discontinuing its progression and/or reversing CKD have to be the primary targets for the clinical management of these patients. 


\section{Riassunto}

Una stretta relazione tra la funzione cardiaca e quella renale è presente in tutte le fasi evolutive delle cardiopatie e delle nefropatie, da quelle iniziali asintomatiche a quelle avanzate che culminano nello scompenso cardiaco conclamato e nell' insufficienza renale terminale, rispettivamente. La presenza di una alterazione, anche lieve, della funzione di un apparato condiziona la prognosi e la terapia della patologia conclamata dell'altro apparato. Il riconoscimento precoce delle anormalità della funzione cardiaca e renale è pertanto di notevole rilevanza clinica.

Parole chiave: scompenso cardiaco, disfunzione ventricolare sinistra, insufficienza renale, proteinuria, filtrato glomerulare

\section{References}

1. The role of the kidney in heart failure. Metra M, Cotter G, Gheorghiade M, Dei Cas L, Voors AA. Eur Heart J 2012; 17: 2135-2147.

2. Chronic Kidney Disease Prognosis Consortium. Association of estimated glomerular fi ltration rate and albuminuria with all-cause and cardiovascular mortality in general population cohorts: a collaborative meta-analysis. Lancet 2010; 375: 2073-81

3. Tonelli M, Muntner P, Lloyd A, et al. Using proteinuria and estimated glomerular fi ltration rate to classify risk in patients with chronic kidney disease: a cohort study. Ann Intern Med 2011; 154: 12-21.

4. Sarnak MJ. Kidney disease as a risk factor for development of cardiovascular disease: a statement from the American Heart Association Councils on Kidney in Cardiovascular Disease, High Blood Pressure Research, Clinical Cardiology, and Epidemiology and Prevention. Circulation 2003; 108: 2154-69.

5. Dries DL, Exner DV, Domanski MJ, Greenberg B, Stevenson LW. The prognostic implications of renal insufficiency in asymptomatic and symptomatic patients with left ventricular systolic dysfunction. $J$ Am Coll Cardiol 2000; 35: 681-689.

6. Hillege HL, Nitsch D, Pfeffer MA, et al. Renal function as a predictor of outcome in a broad spectrum of patients with heart failure. Circulation 2006; 113: 671-678.

7. van Deursen VM, Urso R, Laroche C, Damman K, Dahlström U, Tavazzi L, Maggioni AP, Voors AA. Comorbidities in patients with heart failure: an analysis of the European Heart Failure Pilot Survey. Eur J Heart Fail 2014; 16: 103-111.

8. From AM, Leibson CL, Bursi F, et al. Diabetes in heart failure: prevalence and impact on outcome in the population. Am J Med 2006; 119: 591-599.

9. Paoletti E, Bellino D, Cassottana P, Rolla D, Cannella G. Left ventricular hypertrophy in nondiabetic predialysis CKD. Am J Kidney Dis 2005; 46: 320-327.

10. Foley RN, Parfrey PS, Harnett JD, Kent GM, Martin CJ, Murray DC, Barre PE. Clinical and echocardiographic disease in patients starting end-stage renal disease therapy. Kidney Int 1995; 47: 186-192.

11. Levin A. Clinical epidemiology of cardiovascular disease in chronic kidney disease prior to dialysis. Seminars in dialysis 2003; 2: 101-105.

12. Middleton RJ, Parfley PS, Foley RN. Left ventricular hypertrophy in the renal patients. J Am Soc Nephrol 2001; 12: $1079-1084$.

13. Paoletti E, Cassottana P, Bellino D, Specchia C, Messa P, Cannella G. Left ventricular geometry and adverse cardiovascular events in chronic hemodialysis patients on prolonged therapy with ACE inhibitors. Am J Kidney Dis 2002; 40: 728-736.
14. Gross ML, Ritz E. Hypertrophy and fibrosis in the cardiomyopathy of uremia-beyond coronary heart disease. Semin Dial 2008; 21308-318.

15. Schroeder AP, Kristensen BO, Nielsen CB, Pedersen EB. Heart function in patients with glomerulonephritis and mildly to moderately impaired renal function. An echocardiographic study. Blood press 1997; 6: 286-293.

16. Hunter JJ, Chien KR. Signaling pathways for cardiac hypertrophy and failure. N Engl J Med 1999; 341: 1276-1283.

17. de Simone G, Verdecchia P, Pede S, Gorini M, Maggioni AP. Prognosis of inappropriate left ventricular mass in hypertension: the MAVI Study. Hypertension 2002; 40: 470-476.

18. Chinali M, De Marco M, D'Addeo G, Benincasa M, Romano C, Galderisi M, de Simone G. Excessive increase in left ventricular mass identifies hypertensive subjects with clustered geometric and functional abnormalities. $J \mathrm{Hy}$ pertens 2007; 25: 1073-1078.

19. de Simone G, Palmieri V, Koren MJ, Mensah GA, Roman MJ, Devereux RB. Prognostic implications of the compensatory nature of left ventricular mass in arterial hypertension. J Hypertens 2001; 19: 119-125.

20. Palmieri V, Wachtell K, Gerdts E, Bella JN, Papademetriou $\mathrm{V}$, Tuxen $\mathrm{C}$, et al. Left ventricular function and hemodynamic features of inappropriate left ventricular hypertrophy in patients with systemic hypertension: the LIFE study. Am Heart $J$ 2001; 141: 784-791.

21. Mureddu GF, Pasanisi F, Palmieri V, Celentano A, Contaldo F, de Simone G. Appropriate or inappropriate left ventricular mass in the presence or absence of prognostically adverse left ventricular hypertrophy. $J$ Hypertens 2001; 19: 1113-1119.

22. Mureddu GF, Cioffi G, Stefenelli C, Boccanelli A, de Simone G. Compensatory or inappropriate left ventricular mass in different models of left ventricular pressure overload: comparison between patients with aortic stenosis and arterial hypertension. J Hypertens 2009; 27: 642-649.

23. de Simone G, Devereux RB, Kimball TR, Mureddu GF, Roman MJ, Contaldo F, Daniels SR. Interaction between body size and cardiac workload. Influence of left ventricular mass during body growth and adulthood. Hypertension 1998; 31: 1077-1082.

24. Cioffi G, Tarantini L, Frizzi R, et al. Chronic kidney disease elicits excessive increase in left ventricular mass growth in patients at increased risk for cardiovascular events. J Hypertens 2011; 29: 565-573.

25. Nardi E, Palermo A, Mule G, Cusimano P, Cottone S, Cerasola G. Left ventricular hypertrophy and geometry in hypertensive patients with chronic kidney disease. $\mathrm{J} \mathrm{Hy}$ pert 2009; 27: 633-641.

26. Rademakers FE, Rogers WJ, Guier WH, Hutchins GM, Siu CO, Weisfeldt EM, et al. Relation of regional crossfiber shortening to wall thickening in the intact heart. Three-dimensional strain analysis by NMR tagging. Circulation 1994; 89: 1174-1182.

27. de Simone G, Devereux RB. Rationale of echocardiographic assessment of left ventricular wall stress and midwall mechanics in hypertensive heart disease. Eur $J$ Echocardiogr 2002; 3: 192-198.

28. Aurigemma GP, Gottdiener JS, Shemanski L, Gardin J, Kitzman D. Predictive value of systolic and diastolic function for incident congestive heart failure in the elderly: the cardiovascular health study. J Am Coll Cardiol 2001; 37: 1042-1048.

29. de Simone G, Devereux RB, Koren MJ, Mensah GA, Casale PN, Laragh JH. Midwall left ventricular mechanics. An independent predictor of cardiovascular risk in arterial hypertension. Circulation 1996; 93: 259-265.

30. Cioffi G, Rossi A, Targher G, Zoppini G, de Simone G, Devereux RB, et al. Usefulness of subclinical left ventricular midwall dysfunction to predict cardiovascular 
mortality in patients with type 2 diabetes mellitus. Am J Cardiol 2014; 113: 1409-1414.

31. Borlaug BA, Lam CS, Roger VL, Rodeheffer RJ, Redfiels MM. Contractility and ventricular systolic stiffening in hypertensive heart disease insights into the pathogenesis of heart failure with preserved ejection fraction. $J \mathrm{Am}$ Coll Cardiol 2009; 54: 410-418.

32. Mall G, Rambausek M, Neumeister A, Kollmar S, Vetterlein F, Ritz E. Myocardial interstizial fibrosis in experimental uremia-implications for cardiac compliance. Kidney Int 1988; 33: 804-811.

33. Amann K, Wiest G, Zimmer G, Gretz N, Ritz E, Mall G. Reduced capillary density in the myocardium of uremic rats—a stereological study. Kidney Int 1992; 42: 1079-1085.

34. Amann K, Kronenberg G, Gehlen F, Wessels S, Orth S, Münter $\mathrm{K}$, et al. Cardiac remodelling in experimental renal failure-an immunohistochemical study. Nephrol Dial Transplant 1998; 13: 1958-1966.

35. Schwartz K, Chassagne C, Boheler KR. The molecular biology of heart failure. J Am Coll Cardiol 1993; 22: 30-33.

36. Owan TE, Hodge DO, Herges RM, Jacobsen SJ, Roger VL, Redfield MM. Secular trends in renal dysfunction and outcomes in hospitalized heart failure patients. $J$ Card Fail 2006 May; 12: 257-262.

37. McAlister FA, Ezekowitz J, Tonelli M, Armstrong PW. Renal insufficiency and heart failure: prognostic and therapeutic implications from a prospective cohort study. Circulation 2004; 109: 1004-1009.

38. Nieminen MS, Bohm M, Cowie MR, Drexler H, Filippatos GS, Jondeau G, Hasin Y, Lopez-Sendon J, Mebazaa A, Metra M, Rhodes A, Swedberg K, Priori SG, Garcia MA, Blanc JJ, Budaj A, Cowie MR, Dean V, Deckers J, Burgos EF, Lekakis J, Lindahl B, Mazzotta G, Morais J, Oto A, Smiseth OA, Garcia MA, Dickstein K, Albuquerque A, Conthe P, Crespo-Leiro M, Ferrari R, Follath F, Gavazzi A, Janssens U, Komajda M, Morais J, Moreno R, Singer M, Singh S, Tendera M, Thygesen K; ESC Committe for Practice Guideline (CPG). Executive summary of the guidelines on the diagnosis and treatment of acute heart failure: the Task Force on Acute Heart Failure of the European Society of Cardiology. Eur Heart J 2005; 26: 384-416.

39. Schrier RW. Role of diminished renal function in cardiovascular mortality: marker or pathogenetic factor? $J \mathrm{Am}$ Coll Cardiol 2006; 47: 1-8.

40. Shlipak MG, Massie BM. The clinical challenge of cardiorenal syndrome. Circulation 2004; 110: 1514-1517.

41. Elkayam U, Hatamizadeh P, Janmohamed M. The challenge of correcting volume overload in hospitalized patients with decompensated heart failure. J Am Coll Cardiol 2007; 49: 684-686.

42. Forman DE, Butler J, Wang Y, Abraham WT, O'Connor CM, Gottlieb SS, Loh E, Massie BM, Rich MW, Stevenson LW, Young JB, Krumholz HM. Incidence, predictors at admission, and impact of worsening renal function among patients hospitalized with heart failure. $J$ Am Coll Cardiol 2004; 43: 61-67.

43. Weinfeld MS, Chertow GM, Stevenson LW. Aggravated renal dysfunction during intensive therapy for advanced chronic heart failure. Am Heart $J$ 1999; 138: 285-90.

44. Butler J, Forman DE, Abraham WT, Gottlieb SS, Loh E, Massie BM, O'Connor CM, Rich MW, Stevenson LW, Wang Y, Young JB, Krumholz HM. Relationship between heart failure treatment and development of worsening renal function among hospitalized patients. Am Heart J 2004; 147: 331-338.

45. Cowie MR, Komajda M, Murray-Thomas T, Underwood $\mathrm{J}$, Ticho B; POSH Investigators. Prevalence and impact of worsening renal function in patients hospitalized with decompensated heart failure: results of the prospective outcomes study in heart failure (POSH). Eur Heart J 2006; 27: 1216-1222.
46. Cioffi G, Tarantini L, Pulignano G, Del Sindaco D, De Feo S, Opasich C, Di Lenarda A, Stefenelli C, Furlanello F. Prevalence, predictors and prognostic value of acute impairment in renal function during intensive unloading therapy in a community population hospitalized for decompensated heart failure. J Cardiovasc Med 2007; 8: 419-427.

47. Hillege HL, Girbes AR, de Kam PJ, Boomsma F, de Zeeuw D, Charlesworth A, Hampton JR, van Veldhuisen DJ. Renal function, neurohormonal activation, and survival in patients with chronic heart failure. Circulation 2000; 102: 203-210.

48. Saltzman HE, Sharma K, Mather PJ, Rubin S, Adams S, Whellan DJ. Renal dysfunction in heart failure patients: what is the evidence? Heart Fail Rev 2007; 12: 37-47.

49. Cioffi G, Mortara A, Di Lenarda A, Oliva F, Lucci D, Senni M, Cacciatore G, Chinaglia A, Tarantini L, Metra M, Maggioni AP, Tavazzi L, on behalf of Italian Acute Heart Failure Survey. Clinical features, in-hospital and 1year mortality of patients with acute heart failure and severe renal dysfunction. Data from the Italian Registry INHF Outcome. Intern J Cardiol 2014; 172: e96-97.

50. Oliva F, Mortara A, Cacciatore G, et al; IN-HF Outcome Investigators. Acute heart failure patient profiles, management and in-hospital outcome: results of the Italian Registry on Heart Failure Outcome. Eur J Heart Fail 2012; 14: 1208-1217.

51. Heywood JT, Fonarow GC, Costanzo MR, Mathur VS, Wigneswaran JR, Wynne J; ADHERE Scientific Advisory Committee and Investigators. High prevalence of renal dysfunction and its impact on outcome in 118,465 patients hospitalized with acute decompensated heart failure: a report from the ADHERE database. J Card Fail 2007; 13: 422-430.

52. Fonarow GC, Abraham WT, Albert NM, et al; OPTIMIZE-HF Investigators and Hospitals. Influence of a performance-improvement initiative on quality of care for patients hospitalized with heart failure: results of the Organized Program to Initiate Lifesaving Treatment in Hospitalized Patients With Heart Failure (OPTIMIZE-HF). Arch Intern Med 2007; 167: 1493-1502.

53. Fonarow GC, Abraham WT, Albert NM, et al; OPTIMIZE-HF Investigators and Hospitals. Factors identified as precipitating hospital admissions for heart failure and clinical outcomes: findings from OPTIMIZE-HF. Arch Intern Med 2008; 168: 847-854.

54. Tarantini L, Cioffi G, Gonzini L, Oliva F, Lucci D, Di Tano G, Maggioni AP, Tavazzi L; Italian Acute Heart Failure Survey. Evolution of renal function during and after an episode of cardiac decompensation: results from the Italian survey on acute heart failure. $J$ Cardiovasc Med 2010; 11: 232-243.

55. Bibbins-Domingo K, Lin F, Vittinghoff E, BarrettConnor E, Grady D, Shlipak MG. Renal insufficiency as an independent predictor of mortality among women with heart failure. J Am Coll Cardiol 2004; 44: 1593-1600.

56. Ezekowitz J, McAlister FA, Humphries KH, Norris CM, Tonelli M, Ghali WA, Knudtson ML; APPROACH Investigators. The association among renal insufficiency, pharmacotherapy, and outcomes in patients with heart failure and coronary artery disease. $J$ Am Coll Cardiol 2004; 44: 1587-1592.

57. Knight EL, Glynn RJ, McIntyre KM, Mogun H, Avorn J. Predictors of decreased renal function in patients with heart failure during angiotensin-converting enzyme inhibitor therapy: results from the studies of left ventricular dysfunction (SOLVD). Am Heart J 1999; 138: 849-855.

58. Ahmed A, Fonarow GC, Zhang Y, Sanders PW, Allman RM, Arnett DK, Feller MA, Love TE, Aban IB, Levesque R, Ekundayo OJ, Dell'Italia LJ, Bakris GL, Rich MW. Renin-angiotensin inhibition in systolic heart failure and chronic kidney disease. Am J Med 2012; 125: 399-410. 
59. Lahoz C, Mostaza JM, Mantilla MT, Taboada M, Tranche S, Lopez-Rodriquez I, Monteiro B, Soler B, Sanchez-Zamorano MA, Martin-Jadraque R. Achievement of therapeutic goals and utilization of evidencebased cardiovascular therapies in coronary heart disease patients with chronic kidney disease. Am J Cardiol 2008; 101: 1098-1102.

60. Patel UD, Hernandez AF, Liang L, Peterson ED, LaBresh KA, Yancy CW, Albert NM, Ellrodt G, Fonarow GC. Quality of care and outcomes among patients with heart failure and chronic kidney disease: a Get With the Guidelines-Heart Failure Program study. Am Heart J 2008; 156: 674-681.

61. Berger AK, Duval S, Manske C, Vazquez G, Barber C, Miller L, Luepker RV. Angiotensin-converting enzyme inhibitors and angiotensin receptor blockers in patients with congestive heart failure and chronic kidney disease. Am Heart J 2007; 153: 1064-1073.

62. Effect of metoprolol $\mathrm{CR} / \mathrm{XL}$ in chronic heart failure: Metoprolol CR/XL Randomised Intervention Trial in Congestive Heart Failure(MERIT-HF). Lancet 1999; 353: 2001-2007.

63. The Cardiac Insufficiency Bisoprolol Study II (CIBIS II): a randomized trial. CIBIS II investigators and committees. Lancet 1999; 353: 9-13.

64. Bristow MR, Gilbert EM, Abraham WT, et al. Carvedilol produces dose-related improvements in left ventricular function and survival in subjects with chronic heart failure. MOCHA Investigators. Circulation 1996; 94: 2807-2816.

65. Packer M, Bristow MR, Cohn JN, et al. The effect of carvedilol on morbidity and mortality in patients with chronic heart failure. U.S. Carvedilol Heart Failure Study Group. N Engl J Med 1996; 334: 1349-1355.

66. Zugck C, Haunstetter A, Kruger C, et al. Impact of betablocker treatment on the prognostic value of currently used risk predictors in congestive heart failure. $\mathrm{J} \mathrm{Am} \mathrm{Coll}$ Cardiol 2002; 39: 1615-1622.

67. Bart BA, Gattis WA, Diem SJ, O'Connor CM. Reasons for underuse of angiotensin-converting enzyme inhibitors in patients with heart failure and left ventricular dysfunction. Am J Cardiol 1997; 79: 1118-1120.

68. Bakris GL, Weir MR. Angiotensin-converting enzyme inhibitor-associated elevations in serum creatinine: is this a cause for concern? Arch Intern Med 2000; 160: 685-693.

69. Ahmed A. Use of angiotensin-converting enzyme inhibitors in patients with heart failure and renal insufficiency: how concerned should we be by the rise in serum creatinine? J Am Geriatr Soc 2002; 50: 1297-1300.

70. Spinar J, Parenica J, Vitovec J, et al. Baseline characteristics and hospital mortality in the Acute Heart Failure Database (AHEAD) Main registry. Crit Care 2011; 15: R291.

71. Bowling CB, Sanders PW, Allman RM, et al. Effects of enalapril in systolic heart failure patients with and without chronic kidney disease: Insights from the SOLVD Treatment trial. Int J Cardiol 2013; 167: 151-156.

72. Pita-Fernández S, Chouciño-Fernández T, Juega-Puig J, Seoane-Pillado T, López-Calviño B, Pértega-Díaz S, Pedreira-Andrade JD, Gil-Guillén V. A randomized clinical trial to determine the effect of angiotensin inhibitors reduction on creatinine clearance and haemoglobin in heart failure patients with chronic kidney disease and anaemia. Int J Clin Pract 2014 Jul 16. doi: 10.1111/ijcp.12475. 